\title{
Nutritional and antioxidant potential of canjiqueira fruits affected by maturity stage and thermal processing
}

Potencial nutritivo e antioxidante de frutos de canjiqueira afetados pelo estádio de maturação e pelo processamento térmico

\section{Mariana Ferreira Oliveira Prates ${ }^{\mathrm{I}}$ Raquel Pires Campos $^{\mathrm{I}}$ Michelly Morais Barbosa da Silva Maria Lígia Rodrigues Macedo ${ }^{I I}$ Priscila Aiko Hiane ${ }^{I}$ Manoel Mendes Ramos Filho ${ }^{I}$}

\section{ABSTRACT}

The effect of jelly processing on the chemical properties, nutrients, antinutritional factors, bioactive compounds, and antioxidant activity of unripe and ripe canjiqueira fruits was evaluated. The fruits were collected from Pantanal regions at two different ripening stages and were used to produce jellies. The processing affected the chemical characteristics and the content of all nutrients, except for the lipids. Moisture and protein content reduced, whereas the energy value increased. The phytic acid found in fresh fruits was eliminated after processing, and the trypsin inhibitors were reduced, especially in ripe fruits. Lectin activity was not verified in unripe and ripe fruits and jellies. The levels of bioactive compounds were reduced after jelly processing, but their retention was higher in unripe fruits. The final levels of bioactive compounds in the jelly made from unripe fruits were higher than that in the jelly made from ripe fruits, whereas the $I C_{50}$ value was lower, indicating higher potential to prevent free radicals damages to human body. Jelly processing proved to be a good alternative to the use of canjiqueira fruits due to the reduction in antinutritional factors and the retention of bioactive compounds.

Key words: Byrsonima cydoniifolia A. Juss., jelly, antioxidant activity. RESUMO

Avaliou-se o efeito do processamento de geleia nas características químicas, nos nutrientes, fatores antinutricionais, compostos bioativos e atividade antioxidante de frutos de canjiqueira verdes e maduros. Os frutos foram coletados em regiões de Pantanal em dois estádios de maturação e utilizados para produzir geleias. O processamento afetou as características químicas e os níveis dos nutrientes estudados, exceto de lipídeos. A umidade e o conteúdo proteico reduziram, enquanto o valor energético aumentou. $O$ ácido fitico detectado nos frutos frescos foi eliminado após o processamento e os níveis de inibidores trípticos reduziram, especialmente nos frutos maduros. Não foi verificada atividade de lectinas nos frutos e geleias. Os níveis dos compostos bioativos estudados reduziram após o processamento das geleias, sendo sua retenção maior nos frutos verdes. Os níveis de compostos bioativos na geleia de frutos verdes foram maiores que nos frutos frescos maduros, enquanto o valor de $I C_{50}$ foi menor, indicando maior potencial em prevenir danos à saúde causados pelos radicais livres. A geleia se mostrou uma boa alternativa para utilização dos frutos de canjiqueira, devido à redução dos fatores antinutricionais e à retenção dos compostos bioativos.

Palavras-chave: Byrsonima cydoniifolia A. Juss., geleia, atividade antioxidante.

\section{INTRODUCTION}

Byrsonima cydoniifolia A. Juss., locally called canjiqueira, is a Malpighiaceae very common in Pantanal, where it is found under different ecological conditions. It can be found in dry and flooded soils (SANTOS et al., 2008). This species can form large clusters called canjiqueirais, which favor the fruit harvest by rural communities, who used them to make juice (DAMASCENO JÚNIOR \& SOUZA, 2010).

There is a potential and growing market for the use of native fruits in diet, but it is under-utilized by local communities, and the fruits are explored only (RIBEIRO \& RODRIGUES, 2006). Reports about their nutritional properties can improve their use and build up a new source of nutrients and market for rural communities of the Pantanal region. Some studies have showed that diets rich in antioxidant compounds contribute to reduce the incidence of chronic diseases (GONZALEZ, 2006). This protective

\footnotetext{
'Unidade de Tecnologia de Alimentos, Universidade Federal de Mato Grosso do Sul (UFMS), Cidade Universitária, CP 549, 79070-900,

Campo Grande, MS, Brasil. E-mail: fo.mariana@yahoo.com.br. *Corresponding author.

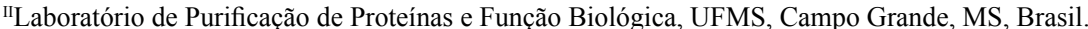


effect is related to physiologically active substances such as carotenoids, vitamins, phenolic compounds, and minerals (MORAES \& COLLA, 2006). Great attention has been given to fruits in general because of the incidence of antioxidant compounds, but data about the effects of processing, the antioxidant capacity, such as those of jelly processing, are still scarce (KIM \& PADILLA-ZAKOUR, 2004).

Processing cause nutritional changes in foods, but it also makes them more sensorially appealing to the consumers and increases their shelf life (SILVA et al., 2006). Processing can affect the levels of some bioactive compounds of fruits and vegetables due to the exposure to oxygen and long periods of high temperature (RODRIGUEZ-AMAYA, 1999). There are many studies on the effects of processing on food nutrients, but papers involving the retention of bioactive compounds are recent and data on native fruits are scarce.

The objectives of this research were (1) to study the effect of jelly processing on chemical characteristics, nutrients, and antinutritional factors of unripe and ripe canjiqueira fruits and (2) to evaluate the retention of bioactive compounds and the antioxidant properties of unripe and ripe canjiqueira fruits submitted to jelly processing.

\section{MATERIAL AND METHODS}

Canjiqueira fruits were harvested in Pantanal regions (19 $\left.34^{\prime} 37^{\prime \prime} \mathrm{S} ; 5^{\circ} 00^{\prime} 42^{\prime \prime} \mathrm{W}\right)$ in the state of Mato Grosso do Sul at two ripening stages based on the fruit skin color: unripe (green) and ripe (yellow). Three batches of sixty fruits from each stage of maturity were randomly selected, washed, and sanitized with a sodium hypochlorite solution $\left(200 \mu \mathrm{g} \mathrm{mL}^{-1}\right)$. After removing the seeds using a stainless steel knife, the pulp was crushed. The pulps were obtained in triplicate and were used to produce canjiqueira jellies at a fruit pulp: sucrose ratio of 40:60 (w/w) in triplicate. Approximately $200 \mathrm{~g}$ of each pulp were homogenized in a blender with $200 \mathrm{~g}$ of water and heated until it began to boil, when $300 \mathrm{~g}$ of sucrose was added. The boiling continued for about 8 minutes, until the soluble solids content of $68^{\circ}$ Brix was achieved. The temperature reached $104^{\circ} \mathrm{C}$. After the heating was stopped, tartaric acid was added $(0.80 \mathrm{~g}$ to the unripe fruit jelly and $1.25 \mathrm{~g}$ to ripe fruit jelly) to prevent sucrose crystallization and preserve the product. A total of $328.52 \mathrm{~g}$ of each jelly was produced, stored in previously sterilized hot glass flasks, sealed, and cooled under running water, leaving headspace to allow for vacuum formation.
The pulp yield was calculated as the amount of pulp to produce $100 \mathrm{~g}$ of jelly.

Soluble solids, $\mathrm{pH}$, and titratable acidity of unripe and ripe fruit pulps and jellies of both stages of maturity were analyzed and compared. The soluble solids were determined using a refractometer (Hanna, $\mathrm{HI} 96801$ ) and expressed in ${ }^{\circ}$ Brix. The $\mathrm{pH}$ was measured using a digital potentiometer (Analyser, 300M), according to AOAC Method No. 981.12, and titratable acidity was determined by potentiometric titration with $\mathrm{NaOH} 0.1 \mathrm{M}$ until $\mathrm{pH} 8.10$, according to AOAC official method 942.15 (AOAC, 1995). Reducing sugars (glucose), disaccharides in non-reducing sugars (sucrose), and starch were determined according to AOAC official method 31.034-6 (AOAC, 1995).

Parameters to estimate the effect of processing were determined in $100 \mathrm{~g}$ of fresh and processed pulp with results expressed on fresh weight considering that $100 \mathrm{~g}$ of jelly has $60.8 \mathrm{~g}$ of fresh pulp.

The moisture content of fresh and processed pulp was determined by oven drying at $105^{\circ} \mathrm{C}$ for 8 hours to constant mass, according to AOAC official method 31.1.02 (AOAC, 1995). Total nitrogen was determined by micro-Kjeldahl assay according to the AOAC official method 31.1.08 (AOAC, 1995). Total lipids were determined by Sohxlet extraction according to the AOAC official method 31.4.02, with previously acid extraction (AOAC, 1995). The total caloric value was estimated using the Atwater conversion values (WILSON et al., 1982), and the results were expressed in kcal. The ash content was determined by calcination in a muffle at $550^{\circ} \mathrm{C}$ to constant mass, by the AOAC official method 31.1.04 (AOAC, 1995).

Phytic acid was determined according to the method of LATTA\& ESKIN (1980), and the results were expressed as mg of phytic acid $100 \mathrm{~g}^{-1}$ of sample. The levels of trypsin inhibitors were determined by enzymatic assay with bovine trypsin and substrate N'-benzoyl-DL-arginine-paranitroanilide (BAPNA). The pre-incubation medium consisted of a $0.05 \mathrm{M}$ Tris-HCl buffer, $\mathrm{pH} 8.0$; bovine trypsin; and different concentrations of the extracts (1 to $10 \mathrm{mg}$ ). Preincubation was performed in a water bath at $37^{\circ} \mathrm{C}$ followed by the addition of BAPNA reagent. The reaction stopped with the addition of $30 \%$ acetic acid. The p-nitro aniline formation was measured spectrophotometrically at 410nm (FEMTO, 482), and the results were expressed as inhibitor units (UI) $\mathrm{mg}^{-1}$ (MACEDO et al., 2003). Hemagglutination assays (lectin) were performed in microtitre plates using serial dilutions of $50 \mathrm{~mL}$ of $0.15 \mathrm{M} \mathrm{NaCl}, 50 \mu \mathrm{L}$ of total extracts, and $50 \mu \mathrm{L}$ of a $2 \%$ suspension of human erythrocytes type A (FREIRE et al., 2002). 
The ascorbic acid content was determined by titration with 2,6 dichlorophenolindophenol according to the AOAC official method 967.21 (AOAC, 1995), and the results were expressed as $\mathrm{mg}$ of ascorbic acid $100 \mathrm{~g}^{-1}$ of sample. Bioactive compounds extraction followed ROESLER et al. (2007) methodology. An extract of each sample in triplicate was obtained with ethanol:water $(60: 40 \mathrm{v} / \mathrm{v})$ solvent. The hidroalcoholic solvent was previously defined to optimize the extraction of the bioactive compounds under study.

The total phenolics compounds were determined according to SWAIN \& HILLIS (1959) using the Folin-Ciocalteu reagent, and the results were expressed as $\mathrm{mg}$ of gallic acid equivalents (GAE) $100 \mathrm{~g}^{-1}$ of fresh pulp. Tannin content was measured by spectroscopy with Folin-Dennis reagent according to AOAC official method 952.03 (AOAC, 1995), and the results were expressed as mg of tannic acid equivalents (TAE) $100 \mathrm{~g}^{-1}$ of fresh pulp.

The antioxidant and free radicalscavenging activity were measured by the DPPH method (BRAND-WILLIAMS et al., 1995). A 3.9mL aliquot of a $0.0634 \mathrm{mM}$ of DPPH solution in methanol was added to $0.1 \mathrm{~mL}$ of each extract and shaken vigorously. The tubes were placed in a warm bath at $27^{\circ} \mathrm{C}$ for $20 \mathrm{~min}$. A control reaction was prepared as described above without the extract, and methanol was used for baseline correction. Absorbance was measured at $517 \mathrm{~nm}$, and it curve was drawn with the different extract concentrations. The $\mathrm{IC}_{50}$ value was defined as the concentration of sample in mg. $\mathrm{mL}^{-1}$ of fresh pulp necessary to reduce the initial DPPH concentration by $50 \%$.
The experimental design was completely randomized in a factorial $2 \times 2$ (maturity stage $\mathrm{x}$ processing), with 3 replicates and thirty fruits for each experimental plot. The data were subjected to ANOVA, and the means were compared by the Tukey test (Origin 7.0, OriginLab, Northampton, MA) to examine significant differences between variables $(\mathrm{P}<0.05)$.

\section{RESULTS AND DISCUSSION}

The effects of fruit maturity stage and jelly processing on the chemical characteristics, nutrients, and antinutritional factors of canjiqueira fruits are shown in table 1 . The jelly yield was $66 \%$.

Considering the fresh pulp, the $\mathrm{pH}$ was higher $(\mathrm{P}<0.05)$ in ripe than in unripe fruits. The titratable acidity (TA) did not differ statistically, although results were lower in ripe fruits. After processing, the $\mathrm{pH}$ significantly reduced in unripe and ripe fruits, and it did not differ between unripe and ripe processed pulp. The TA increased as result of jelly processing (Table 1), due to the addition of tartaric acid to improve preservation of product and gelatinization of the jelly, and it was higher $(\mathrm{P}<0.05)$ in unripe processed pulp.

Higher levels of soluble solids (SS) were found in fresh unripe pulp (Table 1), which was attributed to the presence of some interfering substances in the matrix studied that could not be identified by the refratometric method used. Tannins can form complexes with proteins resulting in agglomerates and, depending on concentration of these compounds, they can form precipitates causing

Table 1 - Chemical parameters, nutrients, and antinutritional factors of fresh pulp and processed pulp of unripe and ripe canjiqueira fruits.

\begin{tabular}{|c|c|c|c|c|}
\hline \multirow{2}{*}{ Characteristics } & \multicolumn{4}{|c|}{------------------------- Unripe fruits ---------------------- } \\
\hline & Fresh pulp & Processed pulp & Fresh pulp & Processed pulp \\
\hline $\mathrm{pH}$ & $3.27 \pm 0.06^{\mathrm{b}}$ & $3.02 \pm 0.05^{\mathrm{c}}$ & $3.41 \pm 0.03^{\mathrm{a}}$ & $3.06 \pm 0.04^{\mathrm{c}}$ \\
\hline Titratable acidity $\left({\left.\mathrm{g} 100 \mathrm{~g}^{-1}\right)}\right.$ & $1.08 \pm 0.04^{\mathrm{c}}$ & $2.42 \pm 0.06^{\mathrm{a}}$ & $0.960 \pm 0.07^{\mathrm{c}}$ & $1.93 \pm 0.11^{\mathrm{b}}$ \\
\hline Soluble solids ( $\left.{ }^{\circ} \mathrm{Brix}\right)$ & $17.00 \pm 0.30^{\mathrm{b}}$ & $68.60 \pm 1.71^{\mathrm{a}}$ & $12.60 \pm 0.72^{\mathrm{c}}$ & $68.97 \pm 1.42^{\mathrm{a}}$ \\
\hline Dry matter $\left({\left.\mathrm{g} 100 \mathrm{~g}^{-1}\right)}\right.$ & $24.26 \pm 0.10^{\mathbf{b}}$ & $77.09 \pm 0.75^{\mathrm{a}}$ & $24.62 \pm 0.25^{\mathrm{b}}$ & $73.53 \pm 2.94^{\mathrm{a}}$ \\
\hline Moisture $\left({\left.\mathrm{g} 100 \mathrm{~g}^{-1}\right)}\right.$ & $75.74 \pm 0.10^{\mathrm{a}}$ & $22.91 \pm 0.75^{\mathbf{b}}$ & $75.38 \pm 0.25^{\mathrm{a}}$ & $26.47 \pm 2.94^{\mathrm{b}}$ \\
\hline Crude protein $\left({\left.\mathrm{g} 100 \mathrm{~g}^{-1}\right)}\right.$ & $0.980 \pm 0.09^{\mathbf{b}}$ & $0.630 \pm 0.10^{\mathbf{c}}$ & $1.33 \pm 0.08^{\mathrm{a}}$ & $0.720 \pm 0.13^{\mathrm{c}}$ \\
\hline Lipids $\left({\left.\mathrm{g} 100 \mathrm{~g}^{-1}\right)}\right.$ & $2.92 \pm 0.01^{\mathbf{b}}$ & $2.86 \pm 0.08^{\mathbf{b}}$ & $3.45 \pm 0.01^{\mathrm{a}}$ & $3.36 \pm 0.05^{\mathrm{a}}$ \\
\hline $\operatorname{Ash}\left(\mathrm{g} 100 \mathrm{~g}^{-1}\right)$ & $1.03 \pm 0.01^{\mathrm{a}}$ & $0.740 \pm 0.01^{\mathbf{b}}$ & $0.990 \pm 0.02^{\mathrm{a}}$ & $0.710 \pm 0.04^{\mathbf{b}}$ \\
\hline Energy (kcal $\left.100 \mathrm{~g}^{-1}\right)$ & $107.52 \pm 0.36^{\mathbf{b}}$ & $327.27 \pm 6.00^{\mathrm{a}}$ & $111.97 \pm 0.92^{b}$ & $312.76 \pm 13.00^{\mathrm{a}}$ \\
\hline Phytic acid (mg $\left.100 \mathrm{~g}^{-1}\right)$ & $0.760 \pm 0.04^{\mathrm{a}}$ & n.d. & $0.790 \pm 0.03^{\mathrm{a}}$ & n.d. \\
\hline Lectins & n.d. & n.d. & n.d. & n.d. \\
\hline Trypsin inhibitors (UI $\mathrm{mg}^{-1}$ ) & $0.580 \pm 0.50^{\mathrm{a}}$ & $0.330 \pm 0.23^{\mathbf{b}}$ & $0.550 \pm 0.22^{\mathrm{a}}$ & $0.140 \pm 0.96^{\mathrm{c}}$ \\
\hline
\end{tabular}

n.d.: not detected; UI: inhibitor units. Means followed by different letters in the same line are significantly different (P<0.05), according to the Tukey test. 
turbidity (CARVALHO et al., 2006). This turbidity may have interfered in the refractometer reading, increasing the results of SS in unripe canjiqueira fruits. In order to know the sugar content of the samples, reducing and non-reducing sugars and starch content were determined in all samples. The levels of reducing and non-reducing sugars were significantly higher $(\mathrm{P}<0.05)$ in fresh ripe pulp (respectively

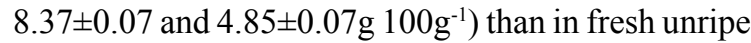
pulp (respectively $6.40 \pm 0.07$ and $3.97 \pm 0.18 \mathrm{~g} 100 \mathrm{~g}^{-1}$ ), whereas the starch content was higher $(\mathrm{P}<0.05)$ in

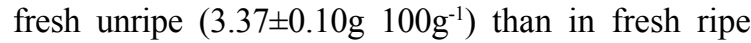

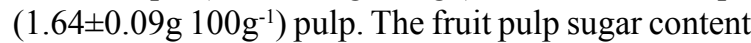
interferes with the amount of sucrose to be added to reach the desired SS on jellies.

The SS of unripe and ripe fruit jellies (Table 1) did not differ statistically $(\mathrm{P}>0.05)$ and were close to the $68^{\circ}$ Brix value determined just after processing. The levels of SS and moisture of the jellies produced are within the minimum value of $62 \%$ soluble solids and the maximum of $38 \%$ moisture required by legislation (BRASIL, 1978).

The levels of protein and lipids were higher $(\mathrm{P}<0.05)$ in fresh ripe pulp (Table 1), when compared to those of fresh unripe pulp, but they were lower than those reported by ABADIO FINCO et al. (2012) for ripe pulp of murici (Byrsonima crassiflora) fruits (of the same family of canjiqueira fruits): 1.89 and

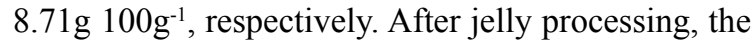
levels of moisture, protein, and ash reduced $(\mathrm{P}<0.05)$ in unripe and ripe fruits, and were statistically equal in both jellies produced (Table 1). The lipid levels remained stable. Processing increased the energy value of fresh unripe and ripe pulps $(\mathrm{P}<0.05)$, due to the addition of sugar, and there was no statistical difference between the two jellies produced.

An undesirable characteristic of fresh canjiqueira fruits, detected in previously experiments on canjiqueira, is the high content of trypsin inhibitors (TI) (Table 1). These compounds inactivate proteolytic enzymes thus reducing the nutritional value of foods (BONETT et al., 2007). In order to reduce their TI levels, canjiqueira fruits were submitted to jelly processing. The initial contents of TI were statistically equal in fresh unripe and ripe fruits (Table 1). Processing reduced $(\mathrm{P}<0.05)$ the levels of this antinutritional factor in both samples. Unripe

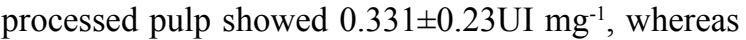

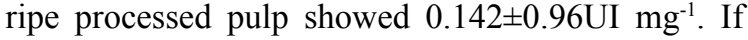
consumed in high amounts, the unripe fresh fruits can reduce the bioavailability of dietary proteins and for this reason the consumption of processed fruit pulp is recommended, especially when made from ripe fruits.

The phytic acid content of fresh unripe and ripe pulps was statistical equal ( $\mathrm{P}>0.05$ ) (Table 1) and higher than those reported for pulp and seed of baru (Dipteryx alata Vog), 0.27 and $0.16 \mathrm{mg}$ of phytic acid $100 \mathrm{~g}^{-1}$, respectively (SANO et al., 2004). After jelly processing, the phytic acid was eliminated from unripe and ripe canjiqueira pulps. Lectin activity was not verified in any samples studied (Table 1).

Antioxidant properties of fresh and processed unripe and ripe canjiqueira pulps are shown in table 2. The ascorbic acid content of fresh unripe and ripe canjiqueira pulps did not differ $(\mathrm{P}>0.05)$ and was substantially higher than that observed in murici (Byrsonima crassifolia) fresh fruits, $0.3 \mathrm{mg} 100 \mathrm{~g}^{-1}$ (CANUTO et al., 2010). Fresh unripe pulp showed higher levels of total phenols (TP) and tannins and lower values of $\mathrm{IC}_{50}$ than those of fresh ripe pulp (Table 2), indicating higher antioxidant capacity (AC). Fresh ripe pulp showed lower TP content than that of ripe murici (Byrsonima crassifolia) pulp, 298.26mg GAE $100 \mathrm{~g}^{-1}$ (ABADIO FINCO et al., 2012), and lower tannin content than that reported for guarirova (Syagrus oleracea (Mart.) Becc.) pulp, $83.47 \mathrm{mg}^{\mathrm{TAE}} 100 \mathrm{~g}^{-1}$ (NOZAKI, 2012).

Table 2 - Bioactive compounds and antioxidant activity of fresh pulp and processed pulp of unripe and ripe canjiqueira fruits.

\begin{tabular}{|c|c|c|c|c|}
\hline \multirow{2}{*}{ Characteristics } & \multirow{2}{*}{ Fresh pulp } & \multirow[b]{2}{*}{ Processed pulp } & \multirow[b]{2}{*}{ Fresh pulp } & \multirow[b]{2}{*}{ Processed pulp } \\
\hline & & & & \\
\hline Ascorbic acid (mg 100g $\left.{ }^{-1}\right)$ & $119.22 \pm 3.93^{\mathrm{a}}$ & $71.80 \pm 7.39^{\mathbf{b}}$ & $135.16 \pm 14.53^{\mathrm{a}}$ & $45.74 \pm 6.20^{\mathrm{c}}$ \\
\hline Retention (\%) & \multicolumn{2}{|c|}{60.22} & \multicolumn{2}{|c|}{33.84} \\
\hline Total phenols (mg GAE $100 \mathrm{~g}^{-1}$ ) & $501.18 \pm 7.61^{\mathrm{a}}$ & $312.71 \pm 7.67^{\mathbf{b}}$ & $152.57 \pm 7.84^{\mathrm{c}}$ & $66.06 \pm 4.56^{\mathrm{d}}$ \\
\hline Retention (\%) & \multicolumn{2}{|c|}{62.39} & \multicolumn{2}{|c|}{43.30} \\
\hline Tannins (mg TAE $100 \mathrm{~g}^{-1}$ ) & $195.94 \pm 3.14^{\mathrm{a}}$ & $100.46 \pm 4.58^{\mathrm{b}}$ & $54.81 \pm 2.23^{\mathrm{c}}$ & $3.62 \pm 0.06^{\mathrm{d}}$ \\
\hline Retention (\%) & \multicolumn{2}{|c|}{51.27} & \multicolumn{2}{|c|}{6.60} \\
\hline $\mathrm{IC}_{50}\left(\mathrm{mg} \mathrm{mL}^{-1}\right)$ & $4.63 \pm 0.83^{d}$ & $6.18 \pm 0.78^{\mathfrak{c}}$ & $12.83 \pm 1.64^{\mathbf{b}}$ & $17.47 \pm 0.89^{\mathrm{a}}$ \\
\hline
\end{tabular}

Means followed by different letters in the same column are significantly different $(\mathrm{P}<0.05)$, according to the Tukey test. 
The levels of total phenols (TP) were significantly higher $(\mathrm{P}<0.05)$ in fresh unripe pulp. Fresh unripe pulp even showed higher levels of tannins $(\mathrm{P}<0.05)$, and the $\mathrm{IC}_{50}$ value of ripe canjiqueira fruits was higher than that reported for ripe murici (Byrsonima crassiflora) fruits, $6.56 \mathrm{mg}$ $\mathrm{mL}^{-1}$ (ABADIO FINCO et al., 2012).

Unripe processed pulp showed higher retention of AA, TP, and tannins than ripe fruit jelly. Processing reduced the antioxidant capacity of the fruit. Both unripe and ripe fruit jellies showed higher $\mathrm{IC}_{50}$ value, which is related to lower antioxidant activity. The reduce in AA content resulting from jelly processing was previously reported by SILVA et al. (2006) in jelly made of orange juice, with $75 \%$ of retention in ascorbic acid content. Thermal processing can reduce the levels of phytochemicals due to lost of cellular integrity by enzymatic action or by factors such as light and oxygen (VOLDEN et al., 2008).

Unripe and ripe canjiqueira fruits were submitted to the same processing conditions, but the retention and the levels of all bioactive compounds studied were higher in unripe fruits. This can be attributed to enzymatic action, which is commonly higher in ripe fruits, and can reduce the levels of some bioactive compounds. Even after jelly processing, unripe pulp maintained greater levels of bioactive compounds and better preserved the antioxidant activity than did the ripe pulp. Data showed that the consumption of unripe fruit and jelly is not advisable due to high levels of antinutritional factors. Because of the trypsin inhibitors observed in unripe fruit jelly, the bioactive compounds of this product can be recovered by isolation and used to produce nutraceutical products.

Although the jelly processing reduced the antioxidant capacity of canjiqueira fruits, thermal processing was necessary to reduce the levels of trypsin inhibitors and phytic acid observed in fresh fruits.

Future research on canjiqueira fruits should be carried out in order to introduce new accessible processing forms to add value to this fruit, reduce antinutritional factors content, and preserve the levels of nutrients and bioactive compounds as much as possible.

\section{CONCLUSION}

Jelly processing affected the chemical characteristics and the levels of nutrients of canjiqueira fruits. After processing, the levels of proteins reduced and the energy value increased.

The trypsin inhibitor activity decreased after processing, especially in ripe fruit jellies. The consumption of processed pulp is recommended to reduce the effects on protein bioavailability. No lectin activity was observed in the fruits and jellies studied, and the phytic acid was eliminated after processing.

When compared with ripe pulp, even after jelly processing, unripe pulp maintained greater levels of bioactive compounds and better preserved the antioxidant activity.

\section{ACKNOWLEDGEMENTS}

The authors are grateful for the financial support provided by the Coordenação de Aperfeiçoamento de Pessoal de Nível Superior (CAPES).

\section{REFERENCES}

ABADIO FINCO, F.D.B. et al. Physicochemical characteristics and antioxidant activity of three native fruits from brazilian savannah (Cerrado). Alimentos e Nutrição, v.23, n.2, p.179-185, 2012. Available from: <http://serv-bib.fcfar.unesp.br/seer/index.php/ alimentos/article/viewFile/1740/1196>. Accessed: Sept. 20, 2012.

ASSOCIATION OF OFFICIAL ANALYTICAL CHEMISTRY (AOAC). Official methods of analysis. 16.ed. Arlington: AOAC International, 1995. 1025p.

BONETT, L.P. et al. Compostos nutricionais e fatores antinutricionais do feijão comum (Phaseolus vulgaris L.). Arquivos de Ciências da Saúde da Unipar, v.11, p.235-246, 2007. Available from: <http://revistas.unipar.br/saude/article/ viewFile/2044/1786>. Accessed: Ago. 17, 2012.

BRAND-WILLIAMS, W. et al. Use of a free radical method to evaluate antioxidant activity. Lebensmittel-Wissenschaft undTechnologie/Food Science and Technology, v.28, n.1, p.25-30, 1995. Available from: <http://www.sciencedirect.com/science/ article/pii/S0023643895800085>. Accessed: Sept. 14, 2012. doi: 0023-6438/95/010025.

BRASIL. Ministério da Saúde, Agência Nacional de Vigilância Sanitária. Resolução da Comissão Nacional de Normas e Padrões para Alimentos $n^{\circ} 12$, de 24 de julho de 1978. Normas Técnicas Especiais, relativas a alimentos e bebidas. Brasília: Ministério da Saúde, 1978. Available from: $<$ http://www.anvisa. gov.br/legis/resol/12_78_geleia.htm>. Accessed: Jul. 10, 2012

CANUTO, G.A.B. et al. Caracterização físico-química de polpas de frutos da Amazônia e sua correlação com a atividade anti-radical livre. Revista Brasileira de Fruticultura, v.32, p.1196-1205, 2010. Available from: <http://www.scielo.br/ scielo.php?pid=S0100-29452010000400030\&script $=$ sci_arttext $>$. Accessed: Jul. 23, 2012. doi: 10.1590/S0100-29452010005000122.

CARVALHO, E. et al. Influence of wine pectic polysaccharides on the interactions between condensed tannins and salivary proteins. Journal of Agricultural and Food Chemistry, v.54, n.23, p.8936-8944. 2006. Available from: <http://www.ncbi.nlm.nih.gov/pubmed/17090144>. Accessed: Oct. 25, 2012. doi: 10.1021/jf061835h.

DAMASCENO JÚNIOR, G.A.; SOUZA, P.R. Sabores do Cerrado e Pantanal: receitas e boas práticas de utilização. Campo Grande: UFMS, 2010. 141p. 
FREIRE, M.G.M. et al. Isolation and partial characterization of a novel lectin from Talisia esculenta seeds that interferes with fungal growth. Plant Physiology and Biochemistry, v.40, n.1, p.61-68. 2002. Available from: <http://www.sciencedirect.com/science/ article/pii/S0981942801013420>. Accessed: Nov. 02, 2012.

GONZALEZ, C.A. Nutrition and cancer: the current epidemiological evidence. British Journal of Nutrition, v.96, n.1, p.425-455, 2006. Available from: <http://www.ncbi.nlm.nih. gov/pubmed/16923250>. Accessed: Nov. 24, 2012.

KIM, D.O.; PADILLA-ZAKOUR, O.I. Jam processing effect on phenolics and antioxidant capacity in anthocyanin-rich fruits: cherry, plum, and raspberry. Journal of Food Science, v.69, n.9, p.395-400, 2004. Available from: <http://vivo.cornell.edu/display/ AI-18906994689>. Accessed: Nov. 04, 2012. doi: 10.1590/S141370542012000300010 .

LATTA, M.; ESKIN, M. A simple and rapid colorimetric method for phytate determination. Journal of Agricultural and Food Chemistry,v.28,n.6,p.1313-1315,1980.Availablefrom: $<$ http://link. springer.com/article/10.1007\%2Fs00240-012-0473-3\#page-1>. Accessed: Ago. 17, 2012. doi: 10.1007/s00240-012-0473-3.

MACEDO, M.L.R. et al. Trypsin inhibitor from Peltophorum dubium seeds active against pest proteases and its effects on the survival of Anagasta kuehniella (Lepidoptera: Pyralidae). Biochimica at Biophysica Acta, v.1621, n.2, p.170-182, 2003. Available from: $<$ http://www.ncbi.nlm.nih.gov/pubmed/12726993>. Accessed: Jul. 14, 2012. doi: 10.1590/S0101-20612006000300031.

MORAES, F.P.; COLLA, L.M. Alimentos funcionais e nutracêuticos: definição, legislação e benefícios à saúde. Revista Eletrônica de Farmácia, v.3, n.2, p.109-122, 2006 Available from: <www.revistas.ufg.br/index.php/REF/article/ download/2082/2024>. Accessed: Sept. 25, 2012.

NOZAKI, V.T. Potencial nutricional da amêndoa e da polpa da guarirova, Syagrus oleracea (Mart.) Becc. 2012. 100f. Tese (Doutorado em Saúde e Desenvolvimento na Região Centro-Oeste) Curso de Pós-graduação em Saúde e Desenvolvimento na Região Centro-Oeste, Universidade Federal de Mato Grosso do Sul.

RIBEIRO, R.A.; RODRIGUES, F.M. Genética da conservação em espécies vegetais do Cerrado. Revista Ciências Médicas e
Biológicas, v.5, p.253-260, 2006. Available from: $<\mathrm{http}: / / \mathrm{www}$. portalseer.ufba.br/index.php/cmbio/article/viewArticle/4263>. Accessed: Jul. 23, 2012.

RODRIGUEZ-AMAYA, D.B. Changes in carotenoids during processing and storage of foods. Archivos Latinoamericanos de Nutrición, v.49, p.38s-46s, 1999. Available from: <http://www. ncbi.nlm.nih.gov/pubmed/10971842>. Accessed: Jun. 14, 2012.

ROESLER, R. et al. Atividade Antioxidante de frutas do cerrado. Ciência e Tecnologia de Alimentos, v.27, n.1, p.53-60, 2007. Available from: <http://www.scielo.br/pdf/cta/v27n1/09.pdf $>$. Accessed: Ago. 11, 2012.

SANO, S.M. et al. Baru: biologia e uso. Planaltina: Embrapa Cerrados, 2004. 51p.

SANTOS, S.A. et al. Pecuária no Pantanal: em busca da sustentabilidade. In: ALBUQUERQUE, A.C.S.; SILVA, A.G. Brasília: Embrapa Informação Tecnológica; 2008. V.2, p.535-570.

SILVA, P.T. et al. Efeito de diferentes processamentos sobre o teor de ácido ascórbico em suco de laranja utilizado na elaboração de bolo, pudim e geléia. Ciência e Tecnologia de Alimentos, v.26, p.678-682. 2006. Available from: $<$ http://www.scielo.br/pdf/cta/ v26n3/31774.pdf>. Accessed: Ago. 13, 2012.

SWAIN, T.; HILLIS, W.E. The phenolic constituents of Prunus domestica. The quantitative analysis of phenolic constituents. Journal of Science and Food Agriulture, v.10, p.63-68, 1959. Available from: <http://onlinelibrary.wiley.com/doi/10.1002/ jsfa.2740100110/abstract>. Accessed: Jul. 24, 2012.

VOLDEN, J. et al. Effect of thermal treatment on glucosinolates and antioxidant-related parameters in red cabbage (Brassica oleracea L. ssp. capitata f. rubra). Food Chemistry, v.109, p.595-605, 2008. Available from: <http://www.researchgate. net/publication/223730587 Effect of thermal treatment on_glucosinolates_and_antioxidant-related_parameters_in_ red_cabbage_(Brassica_oleracea_L._ssp._capitata_f._rubra) $>$. Accessed: Ago. 19, 2012.

WILSON,E.D.etal.Nutriçãobásica. SãoPaulo:Sarvier, 1982.286p. 